\title{
YO SOY EGIPTO. EL PODER Y LA SEDUCCIÓN DE CLEOPATRA EN LAS ARTES PLÁSTICAS Y EN EL CINE
}

\author{
BELÉN Ruiz GARRIDO
}

Para otra reina

\begin{abstract}
RESUMEN
La figura de Cleopatra ocupa un lugar preferente dentro del universo iconográfico femenino. En la creación del mito, cuya imagen histórica aparece teñida de una buena dosis de leyenda, han participado activamente los artistas a través de la proyección de sus miradas. La soberana de Egipto ofrece los ingredientes más sabrosos para inspirar y alimentar las inquietudes, deseos y sueños masculinos. Desde esta perspectiva, el ejercicio del poder por parte de una mujer no podía entenderse sin la utilización consciente de los componentes estereotipados de la feminidad. Cleopatra, como portadora de una rara y exótica belleza, de un desenfrenado apetito sexual y de pasiones extremas, se convierte en la reina de la seducción que arrastra, arrasa y, finalmente, lleva a la muerte. El país del Nilo brinda, además, el escenario perfecto para los gustadores de lo exótico. El presente trabajo aborda las posibilidades estéticas y expresivas del mito a través de una selección de la producción plástica y cinematográfica más significativa.
\end{abstract}

\section{ABSTRACT}

The figure of Cleopatra has a special place in the female iconographic universe. Her historical image has been frequently tinged with legend, in whose creation artists have taken an active part through their gazes. The sovereign of Egypt provides the most delicious ingredients to inspire and nurture the male interests, desires and dreams. From this point of view the women's practise of power cannot be understood without the conscious use of the female stereotyped elements. Cleopatra with her rare and exotic beauty, her insatiable sexual appetite and her extreme passion turns into seduction queen who draws, destroyes and finally leads to death. The Nile country offers also the perfect location for those who enjoy exotic things. This essay deals with the aesthetics and expressive possibilities of the legend through a selection of the most significant plastic and film works.

Alejandría. Cleopatra (Claudette Colbert) se presenta ante César (Warren William) por sorpresa, envuelta en una alfombra. Desde este original encuentro, el hilo argumental de la película que Cecil B. DeMille filmara en 1934 
quedaba al descubierto: el desafío amoroso y de poder entre el dúo de personajes, al que se sumará Marco Antonio (Henry Wilcoxon), el tercero en discordia. El duelo se centraba en la identificación entre la reina y Egipto, puesto que la ambición romana sobre el rico país del Nilo tenía nombre de mujer. En esa primera escena, César se dirige a Cleopatra llamándola "Egipto", y ella le responde con una invitación que suena a reto: hablar de asuntos políticos en sus aposentos, cenando. El despertar de la pasión no se hace esperar, aunque ésta sea interesada. En la segunda escena, ya en privado, el duelo dialéctico continúa. "Vine a hablar de India, no de las disputas de Egipto", contesta César ante la insistencia de Cleopatra para que la libre de sus enemigos internos. La respuesta es categórica: "Pero yo soy Egipto". Las últimas palabras de Marco Antonio, moribundo en brazos de una desconsolada Cleopatra que le pide irse con él, se dirigen a su amada en los mismos términos: "Te llevaré conmigo, Egipto. Te llevaré conmigo".

\section{UNA FEMME FATALE PARA EL IMAGINARIO MASCULINO. LA CREACIÓN DEL MITO}

La frase, "yo soy Egipto", que en boca de la actriz-soberana suena rotunda y convincente, no podía expresar mejor lo inexorable de semejante asimilación. De hecho el destino del país estaría unido para siempre a la figura de su famosa reina.

La imagen que ha llegado hasta nosotros de Cleopatra se ha ido construyendo a lo largo del tiempo ${ }^{1}$. La mítica reina es uno de los personajes más "inventados" de la historia. La escasez de datos fiables ${ }^{2}$ no sólo no ha sido un impedimento para la recreación de su perfil, sino que ha actuado como estímulo para que escritores y artistas plásticos forjaran un retrato físico y moral definido por las condiciones de la fatalidad. Los autores clásicos fueron los primeros responsables de que la bella y pérfida Cleopatra vagara eternamente por "el más allá" egipcio sin encontrar descanso, marcando el camino que la llevaría directamente a los infiernos. Plutarco la presenta como una mujer culta, dotada para los idiomas y la palabra y, aunque insensata y atolondrada, sumamente calculadora y manipuladora: "pues, según dicen, su belleza no era

1. Un tratamiento conciso del mito a lo largo de los siglos en CALVAT, R.: "Cléopatre de Virgile á Mankiewicz. Origine et évolution d'un mythe", Bulletin de L'Arelam XXXII, 1995, 43-57.

2. Un buen recorrido por los episodios históricos más importantes de su vida en CID LÓPEZ, R. M.: "Cleopatra: Mitos e Historia en torno a una reina", Studia Historica. Historia Antigua 18, 2000, 119-41. Citamos a través de la versión digital del artículo alojada en la página web http://www.gipuzkoakultura.net/ediciones/antiqua/cid5.htm 
tal que deslumbrase o que dejase suspensos a los que la veían; pero su trato tenía un atractivo irresistible y su figura, ayudada de su labia y de una gracia inherente a su conversación, parecía que dejaba clavado un aguijón en el ánimo"3. El historiador griego ponía de manifiesto los prejuicios que definirían los tópicos de la feminidad en su vertiente malsana, al dotar al personaje de las cualidades necesarias para ejercer una atracción abismal sobre un amante convertido en pelele sin voluntad: "Siendo éste el carácter de Antonio, se le agregó por último mal el amor de Cleopatra, porque despertó o inflamó en él muchos afectos hasta entonces ocultos e inactivos, y si había algo de bueno y saludable con que antes se hubiese contenido, lo borró y destruyó completamente"4. Había nacido la encarnación perfecta de la mujer fatal.

La conformación del mito y su futura celebridad cuentan con un hito en la creación de William Shakespeare. La fascinación por la reina egipcia, patente ya en el texto de Plutarco a pesar de tratarse de una figura secundaria, cobra una fuerza particular en Antonio y Cleopatra ${ }^{5}$, la obra teatral que definirá decisivamente la imagen que ha llegado a nuestros días 6 . Partiendo del precedente clásico, donde encuentra su principal fuente, el autor inglés da vida a una Cleopatra ambivalente, poseedora de una desbordante y arrolladora personalidad, cuya multiplicidad de matices descubrimos directamente, con sus apariciones en escena, o a través de otros personajes. En ambos casos, despertará los sentimientos más encontrados, excepto la indiferencia. La reina se presenta como una mujer pasional, activa, poderosa, inteligente, sorpresiva, impetuosa y cruel, y por todo ello, amada, deseada, temida y odiada. Las voces masculinas que la sienten como una amenaza centran el objeto de su ira en la destrucción de su reputación, que, dada su condición femenina, está en relación directa con su licencioso comportamiento moral, de ahí que para César, Pompeyo, Escario o Mecenas sea "lasciva", "puta", "ramera"o "indecente yegua" . Otros personajes la perciben como una mujer "extraña"8, componente de su carácter y conducta que la presenta misteriosa, insondable, sorpresiva, y que tiene que ver con la capacidad admirable, casi sobrehumana, para mostrarse siempre renovada a la mirada ajena: "La edad no puede marchitarla, ni podrá la costumbre/ agostar su infinita variedad: otras mujeres sacian/ los apetitos que despiertan, pero ella da más hambre/ cuanto más satisface. Incluso lo más vil/ se vuelve puro en ella, y hasta los sa-

3. Vidas paralelas, vol. IV, Barcelona 1959, 292.

4. Ibídem, 290.

5. La obra fue estrenada entre finales de 1606 y principios de 1607.

6. Un análisis de la obra en la introducción a SHAKESPEARE, W.: Antonio y Cleopatra, Madrid 2001.

7. Ibídem, 217, 399, 403 y 427.

8. Ibídem, 257. 
cerdotes/ bendicen el ardor de su lujuria"9. El poder de atracción de Cleopatra se vuelve, entonces, inexorable: "Egipto - expone Antonio-, tú sabías demasiado bien/ que mi corazón estaba atado a tu timón con cuerdas/ y que me arrastrarías tras de ti. Sobre mi espíritu/ ya conocías tu total dominio y que/ una sola señal me habría hecho olvidar/ hasta el mandato de los dioses" ${ }^{10}$. No hay vuelta atrás cuando se traspasan los frágiles límites del abismo. Por eso el "nunca la dejará"11 de Enobardo, refiriéndose a Antonio, suena a sentencia de muerte.

Una fuerza irresistible como ésta necesitaba de un componente añadido: traspasar el ámbito material para adentrarse en la esfera de lo sobrenatural, incluso en cuestiones tan terrenales como la belleza o la sensualidad. Las deficiencias físicas que Plutarco descubre en la egipcia, rasgo que al parecer corresponde con la realidad ${ }^{12}$, son subsanadas por el autor inglés, quien atribuye a Cleopatra una belleza indescriptible, fascinante, "hechicera"13, cuyos referentes no se encuentran en ninguna mujer real, sino en las diosas. Cleopatra es Venus o Isis: "En cuanto a su persona,/ cualquier descripción resulta pobre: se tendía en su dosel tejido en oro y seda, más bella/ que Venus, en un cuadro donde la fantasía/ supera a la naturaleza"14. Al impacto de su rara hermosura contribuyen las apariciones públicas, concebidas por el dramaturgo como puestas en escena de exaltada sensualidad. Tanto el decorado como la ambientación participan en la creación de una atmósfera propicia para la embriaguez de los sentidos: "La barcaza donde iba sentada, como un trono bruñido,/ ardía sobre el agua: la popa era de oro trabajado, las velas, púrpura, y tan perfumadas que incluso los vientos/ enloquecían de amor; los remos eran todos de plata,/ y acordaban su ritmo con el sonido de las flautas, haciendo que las aguas en donde golpeaban los siguieran deprisa,/ como si enamoradas de los golpes" ${ }^{15}$. La elección de los personajes del séquito real tampoco resulta arbitraria. Los niños y las doncellas son comparados con cupidos, nereidas y sirenas - "Unos hermosos niños con hoyuelos/ se alzaban a ambos lados, como Cupidos sonrientes/, con abanicos de muchos colores, a los que el viento parecía/ inflamar las mejillas delicadas mientras las refrescaban,/ haciendo lo que deshacían (...) Sus doncellas, como las nereidas,/ otras tantas sirenas, la miraban de frente/ y adornaban la escena con inclinaciones. Al timón,/ una sirena parecida: el velamen de seda se infla con

9. Ibídem, 259-61.

10. Ibídem, 439.

11. Ibídem, 259.

12. CID LÓPEZ, R. M.: Op. cit., capítulo 2: "La ciudad de Alejandría".

13. SHAKESPEARE, W.: Op. cit., 217.

14. Ibídem, 255.

15. Ibídem, 253 y 255. 
el tacto de esas manos suaves como flores,/ que cumplen su tarea con agilidad. De la barcaza/ un extraño perfume invisible golpea los sentidos/ del malecón cercano" $-{ }^{16}$, seres míticos cuya significación relaciona conceptos vitales extremos como el goce, la belleza, el amor, el sexo, la atracción, la tragedia, la destrucción y la muerte.

Semejantes visiones sólo podían ser producto de la imaginación, del sueño, del ensueño o del deseo, lo que, implícitamente, hacía de estos ámbitos agentes creadores de primer orden. Cleopatra y Egipto pasaban a formar parte de la leyenda, trascendiendo la realidad histórica para ocupar un lugar de honor entre los personajes y lugares míticos. Ese "cuadro donde la fantasía supera a la naturaleza", esos "huecos en la naturaleza" ocupados por la ilusión, serían decisivos para el éxito contemporáneo de ambos. De hecho la tragedia shakespeariana reflexiona sobre ciertas cuestiones que posteriormente la sensibilidad romántica y finisecular retomará para renovarlas. La contraposición entre mundos enfrentados, la concepción múltiple de la realidad, la inestabilidad de las percepciones humanas o la posibilidad de transgredir los cánones establecidos, son algunas de ellas ${ }^{17}$.

La Cleopatra creada por Shakespeare, activa en el amor y dueña del poder, responde a esa nueva sensibilidad. La importancia del personaje como encarnación del prototipo de mujer fatal para el imaginario romántico y su derivación finisecular, ya fue anotada por Mario Praz $^{18}$. En el relato Una noche de Cleopatra $^{19}$, Gautier plantea las contradicciones de un personaje que se debate entre la obligación y el deseo, dos opciones irreconciliables de consecuencias trágicas. Para ello, prescinde de los pormenores históricos y se centra en la recreación de personajes y ambientes, a través de descripciones pormenorizadas eminentemente visuales y sensoriales, haciendo de las emociones, de los sentimientos y de los sentidos los verdaderos protagonistas y destinatarios de la obra. El impacto que produce la presencia de la reina responde a estas premisas: "sobre aquel raro cabezal reposaba una testa de infinita seducción, que dio al traste, de una mirada, con medio mundo: una divina y adorable cabeza, la de la más perfecta mujer que nunca ha existido, la más mujer y más reina, un tipo admirable al que los poetas nada han podido añadir, y con el que los soñadores tropiezan siempre en el límite de sus ensueños: no hace falta decir que era Cleopatra" ${ }^{20}$. La dicotomía que perfila el carácter del personaje resulta clave en la concreción del prototipo femenino. Las concesiones al sentimen-

16. Ibídem, 255 y 257.

17. Para un análisis más exhaustivo de esta relación véase la introducción a SHAKESPEARE, W.: Op. cit.

18. The Romantic Agony, Oxford 1988, 214. Cit. en Ibídem, 82.

19. Fue publicado en 1838 como Une nuit de Cléopâtre.

20. Citamos por la edición de Madrid 1924, 5. 
talismo teñido de infelicidad, muy del gusto romántico, se perfilan en la trama argumental: la insatisfacción de dos seres desgraciados que anhelan otras vidas que no les corresponden. Cleopatra, la reina poderosa, y Meiamun, su joven y humilde enamorado, unen sus destinos sólo por una noche, desde la insalvable distancia en que sus diferentes posiciones sociales les sitúan. Pero el duelo amoroso se plantea desde el primer momento desigual. Ser mujer y reina, humana y diosa, se presenta como un dilema de difícil solución. Y si la balanza cae del lado del deber el resultado es devastador. La Venus Cleopatra triunfa mostrando su rostro más inflexible y cruel.

Gautier crea un prototipo físico acorde con los cánones de belleza que ponen de moda los prerrafaelitas en sus obras, y que los simbolistas decadentes llevarán al extremo. En la concreción del tipo de mujer fatal, como ser insondable, imprevisible, visceral, promiscuo e irracional, son comunes las asimilaciones con el mundo animal - prioritariamente los atrayentes y peligrosos felinos y las engañosas serpientes - , las referencias a elementos de la naturaleza - agua o fuego- y el gusto morboso por las actitudes abandonadas, desdeñosas, lánguidas o somnolientas. Dada la riqueza de la descripción no nos resistimos a citarla completa: "Un leve y róseo matiz extendíase bajo la transparente piel de sus mejillas, animando su apasionada palidez; sus sienes, doradas como el ámbar, descubrían en su transparencia una redecilla de venas azules; su serena frente no muy elevada, como las frentes antiguas, pero de una redondez y de una forma perfectas, uníase de irreprochable modo a una severa y recta nariz, en manera de camafeo, de aletas sonrosadas que a la menor emoción se estremecían, como las de una tigresa en celo; la boca pequeña, redonda y muy próxima a la nariz, era de un desdeñoso arqueamiento en el labio superior, y en el inferior, de un resplandeciente carmín y de una húmeda transparencia, fulguraban una sofrenada voluptuosidad y una vitalidad ardorosa e increíble. Sus ojos tenían unos párpados angostos y unas finísimas y casi rectas cejas. No intentaremos dar una idea de ellos; era de un tal fuego, de una tal languidez, de un tan límpido fulgor, que hicieron girar, para contemplarlos, la cabeza de perro del mismísimo Anubis; cada una de las miradas de aquellos ojos era un poema superior a los de Homero o Mimnermo; una señoril barbilla, plena de dominio y fuerza, terminaba aquel encantador perfil" ${ }^{21}$.

El juego que el escritor romántico propone a los lectores y lectoras pasa también por la empatía con el personaje. Las circunstancias vitales de esta Cleopatra romántica completan el retrato con el que las jóvenes burguesas decimonónicas podían identificarse. La reina-mujer sufre los efectos tediosos de una existencia regalada, la insatisfacción de vivir presa en una jaula de oro, encorsetada en unos convencionalismos asfixiantes, anhelando experiencias 
apasionantes, pero sin renunciar al poder que su condición le proporciona y que le hace actuar como una mantis religiosa cuando llega la ocasión.

Una Cleopatra liberada, activa y luchadora en un mundo de hombres, aun con las armas tipificadas de la feminidad a su alcance, como prototipo forjado desde la antigüedad, brindaba, sin la consciencia de sus creadores, y con los matices particulares de cada aportación, un modelo de comportamiento para las mujeres que deseaban escapar de una realidad impuesta, opresiva e irrespirable, invitando a pasar a la acción o al menos ofreciendo la posibilidad de evadirse a través de la imaginación y el sueño.

Esta doble propuesta forma parte de los objetivos que justifican el interés por el exotismo orientalista, cuya eclosión como fenómeno con características definidoras se forja precisamente en el romanticismo para renovarse a través de las poéticas finiseculares ${ }^{22}$. Litvak señala la complejidad de este hecho cultural, literario y artístico en el fin de siglo: "el exotismo significa diversas cosas para diversa gente. Para algunos, aventura, fausto, riqueza, libertad sin límites. Para otros, misterios y sensualidad. Otros más encontraban en él la posibilidad de vivir hasta el límite. Ciertas personas buscaban en las tierras lejanas el paraíso perdido. Existía además el exotismo metafísico (...). Esas regiones lejanas ofrecían al pensamiento un desorden embriagador y la más deliciosa mezcla de nombres, cosas, acontecimientos, doctrinas, creencias, personas, pueblos... Por aquellos años parecía que todo lo novedoso venía de países exóticos"23. Sumergiéndose en espacios y tiempos exóticos, los descontentos tenían la posibilidad de cubrir exigencias vitales: "escapismo, evasión, esteticismo, invenciones fabulosas y fabuladoras, mitos negadores de la realidad cotidiana (...) Un rechazo de la sociedad contemporánea, del maquinismo, del utilitarismo, de las luchas de clases, la pulverización del individuo, la fealdad, la vulgaridad, el conformismo burgués" ${ }^{24}$.

El tratamiento de la temática egipcia ${ }^{25}$ ponía el acento en los aspectos más extremos de estas necesidades. Es lo que Antoni Marí, en referencia al valor

22. El interés historiográfico sobre el género ha dado numerosos títulos, entre los que destacamos GONZÁLEZ ALLANTUD, J.A.: El exotismo en las vanguardias artísticoliterarias, Barcelona 1989; JULLIAN, P.: Les orientalistes, Fribourg 1977; MACKENZIE, J.: Orientalism. History, theory and the arts, Manchester 1995; THORNTON, L.: Les Orientalistes. Peintres voyageurs. 1828-1908, Paris 1983 y La femme dans la peinture orientaliste, Paris 1985 y DAVIES, K.: The Orientalists: Western Artists in Arabia, The Sahara, Persia \& India, New York 2005. En España, el catálogo de la exposición Pintura orientalista en España, Madrid 1988.

23. LITVAK, L.: El sendero del tigre. Exotismo en la literatura española de finales del siglo XIX. 1880-1913, Madrid 1986, 15.

24. Ibídem, 16.

25. Un tratamiento monográfico sobre el interés por Egipto en CLAYTON, P. A.: Redescubrimiento del Antiguo Egipto. Artistas y viajeros del siglo XIX, Barcelona, 1985. 
iniciático del viaje, ha denominado "espacio del deseo": "En el viaje a Oriente toman cuerpo las imaginaciones más osadas; y los más oscuros pensamientos parecen materializarse como dando fe de su realidad. Todos los sentimientos, pensamientos y deseos, que en Occidente parece no tengan lugar, aquí se manifiestan en su inmediatez pasional y lúbrica, en su sensualidad más complaciente y en la perversidad más escondida. El sexo y la violencia encuentran su lugar, la potencia de lo sublime y la armonía de lo pintoresco compiten en ese espacio construido según la forma de la idea" ${ }^{26}$.

En realidad pocos eran los escogidos para emprender físicamente tan difícil trayecto. El gran reto para los creadores era hacer que el público recreara esas vivencias a través de la contemplación o la lectura, pero siempre dejando claro que lo que se relataba o se pintaba quedaba muy lejos de la realidad. Era otra de las claves del exotismo y un aliciente para la continuidad de su vigencia. Cleopatra era una reina legendaria y misteriosa y no podía dejar de serlo. En la mirada de todos, esta figura histórica, ya convertida en mito, no termina de ser y comportarse como el resto de los mortales. Lo contrario hubiera matado el hechizo y con él la fascinación. De ahí que las propuestas para conformar su perfil la mantengan fuera del alcance de cualquier humano, arrastrado inevitablemente a la muerte si la cercanía se produce. Uno de los recursos más útiles era la asimilación de su figura con la estatuaria, tanto para dar cuenta de la perfección de su belleza como para expresar la frialdad de su comportamiento.

Los escritores finiseculares comprendieron la necesidad de mantener al personaje dentro del desafío de la paradoja, elemento clave en la recreación de la fatalidad femenina. En la novela Cleopatra, Henry Rider Haggard continúa la estela romántica al mezclar fantasía, aventura, misterio, rigor documental y una trágica historia sentimental a tres bandas plagada de celos, intrigas, pasiones y muertes, en la que la soberana cumple el inevitable y esperado papel maldito ${ }^{27}$. Desde una perspectiva estética distinta, acorde con las posiciones decadentes y esteticistas, Oscar Wilde (La esfinge sin secreto, 1891, La esfinge, 1894) y Rubén Darío (Metempsicosis, en El canto errante, 1907) hacen de la temática egipcia un motivo recurrente para sumergirse en un trabajo de introspección sobre la singularidad, la extrañeza, el valor existencial de lo transgresor, la resistencia a la mediocridad, la atracción abismal de lo incomprendido, la disparidad de lo misterioso, los cuestionamientos sobre el destino, la belleza, o la necesidad vital de hacer saltar en mil pedazos los estrechos márgenes de la realidad.

26. MARÍ, A.: "Espacio del deseo", en Pintura orientalista en España..., 21.

27. Publicada por primera vez en 1889, la exitosa novela del autor de Las minas del Rey Salomón, Ella y La hija de Amón sigue interesando a los lectores. La editorial Abraxa acaba de publicarla de nuevo en 2006. 
Unido al éxito del exotismo orientalista, el protagonismo de la reina egipcia en la producción literaria y artística se incluye dentro de un interés obsesivo por el universo femenino. La necesidad de tender lazos entre la vida y el arte, llegando a confundirse, el cuestionamiento de los roles atribuidos ancestralmente a los géneros, el comienzo de los movimientos feministas y de emancipación de la mujer, la inestabilidad de los convencionalismos sociales, impuestos y asumidos sin posibilidad de contestación, la atadura de los prejuicios morales, la búsqueda de las esencias perdidas, el anhelo de sacar a flor de piel los más íntimos deseos y ensueños, la valoración de la imaginación y la creatividad para salir de la mediocridad artística y la intención de devolver al arte la máxima capacidad expresiva, se perfilan entre las razones estéticas, sociales y existenciales para el protagonismo absoluto del universo femenino en la creación.

Bajo las miradas masculinas, el mundo de la mujer provoca reacciones contradictorias, como paradójica se percibe su esencia. De un lado, su condición de esposa y madre la hace blanca, pura, intocable e intachable, monja del hogar, obediente y sumisa, perfecta seguidora de la Virgen María, espejo transparente en el que mirarse y modelo de comportamiento abnegado. De otro, su carácter irracional, instintivo y pasional, la convierte en descendiente de Eva, la desobediente inductora al pecado, o mejor de Lilith, la primera mujer, creada de la misma materia que su compañero varón, y por tanto como su igual, cuya rebeldía al sometimiento y el intento de ejercer un comportamiento sexual activo, hace de ella el terror de las embarazadas y los niños y un peligroso agente castrador, pasando a ostentar el dudoso honor de encarnar a la primera femme fatale de la historia.

No fueron los creadores contemporáneos los primeros en dar cuenta de esta oposición dual y de sus preferencias. Tanto Plutarco como Shakespeare enfrentan a Cleopatra con Octavia, hermana de Octavio Augusto y segunda esposa de Marco Antonio, representantes a su vez de dos mundos diametralmente opuestos: Egipto y Roma. Las características de sus respectivos papeles se refuerzan cuando se plantea la oposición. Octavia es una mujer bella, poseedora de una "admirable gravedad y juicio" 28 , en la descripción del autor griego; dulce, abnegada, obediente, sumisa, virtuosa, temerosa de los dioses y respetuosa con la tradición y con el esposo, su "señor", débil e indecisa cuando se trata de elegir, austera, fría y reservada, una "bendición del cielo" para aplacar el corazón de Antonio, por su pudor, belleza y sabiduría, en la obra teatral ${ }^{29}$. Frente a estas cualidades, Cleopatra es la pasión, la energía, el aliento y la vida. 
Parafraseando un célebre título cinematográfico, "el cielo podía esperar", al menos hasta terminar de embriagarse con los placeres terrenales. Estaba claro que esta última visión coparía de forma preferente el imaginario de los artistas finiseculares. Prerrafaelitas, modernistas, simbolistas, estetas y decadentes encuentran en los extremos de lo indescifrable, lo confuso y desconocido, lo fatalmente atrayente, las sensaciones exquisitas e intensas, la sensualidad desbordante y en los sueños oscuros y prohibidos, un material creativo y expresivo de enormes posibilidades.

Capitaneadas por Lilith, toda una pléyade de personajes femeninos pasaron a encarnar distintos prototipos de seducción y fatalidad. Las hijas mitológicas (Venus, Pandora, Medea, Astarté Syriaca, Proserpina, Circe, Helena de Troya), bíblicas (Eva, Salomé, Judit, Dalila), literarias (Salambó, Lorelei, Sidonia von Bork, La Belle Dame sans Merci), históricas (Mesalina, Cleopatra, Lucrecia Borgia) y las bellas atroces (sirenas, esfinges, harpías, medusas, vampiresas y otros seres bestiales), se convirtieron en ídolos de perversidad, codiciados y temidos a un tiempo ${ }^{30}$.

Entre las reinas brindadas por la historia o la leyenda, sin duda Cleopatra ocupa un lugar de honor, como disfraz perfecto para dar cuerpo y voz a la fatalidad consustancial a la mujer. Ella encarna, como hemos visto, buena parte de las peculiaridades que definen a la seductora como criatura que atrae, atrapa y conduce al varón a la perdición, anulando su voluntad y destruyéndolo, haciendo de él una marioneta al servicio de sus deseos. Los recursos empleados en tales acciones forman parte de la considerada esencia femenina, que es utilizada conscientemente por su portadora para vivir una libertad negada, y que, en realidad, forma parte de un discurso machista y misógino. Todas las mujeres que han conseguido parcelas de poder en la historia han debido cargar sobre sus espaldas y reputaciones las consecuencias del hábil empleo de la sabiduría femenina al servicio de sus propósitos. Entre los componentes de esta suerte de destreza para manejarse en un mundo de hombres destacaban la manipulación, el engaño, la soberbia, la falta de escrúpulos y la maldad. A su propia condición, debían añadir pericias ajenas, convirtiéndose en raros y atractivos seres, segregados del resto de los mortales. La erótica del poder se multiplicaba por mil cuando los destinos de un reino o un imperio estaban en manos femeninas.

A todas las habilidades citadas, la soberana de Egipto sumaba su rara belleza, una especial pericia y desinhibición para saciar sus apetitos sexuales, amores y desamores legendarios y un trágico final, en consonancia con la visión exótica que vinculaba al país del Nilo con misterios y pasiones extremas.

30. Véanse DIJKSTRA, B.: Ídolos de perversidad. La imagen de la mujer en la cultura de fin de siglo, Madrid/Barcelona 1986 y BORNAY, E.: Las hijas de Lilith, Madrid 1998. 
La actualización contemporánea del personaje es un indicio de la continuidad de su vigencia. La imagen y personalidad de muchas mujeres célebres se han construido a partir de las referencias brindadas por la insigne antecesora, a través de conexiones más o menos explícitas. Esta suerte de apropiación convierte a la reina María de Rumanía ${ }^{31}$ y a Josephine Baker $^{32}$ en sorprendentes Cleopatras renovadas.

\section{CLEOPATRA Y LAS ARTES PLÁSTICAS}

El interés histórico y legendario del personaje es inseparable de su conversión en objeto artístico. Difícilmente las artes plásticas hubieran podido sustraerse a la fuerza de tal cúmulo de ingredientes y atractivos ${ }^{33}$.

Las primeras representaciones de la reina son coetáneas a su existencia, aunque el catálogo de obras fechadas en el siglo I a.C. es escaso y ambiguo, dado que la identidad de Cleopatra VII a menudo aparece confundida con la de otros miembros femeninos de la dinastía ptolemaica. Las esculturas de bulto redondo, bajorrelieves y monedas de identificación más segura ofrecen dos tipos de imágenes que responden a los referentes estéticos del arte egipcio o grecorromano. El interés del primero por la dimensión sagrada e inmortal de sus individuos sobresalientes materializa efigies despojadas de rasgos característicos. Debemos atender a los bustos y a los perfiles numismáticos del segundo para encontrar elementos fisonómicos que respondan a la singularidad. La mayor parte de ellos muestran rostros de rasgos poderosos, particularmente la nariz grande, afilada o ganchuda, la barbilla prominente y unos pómulos contundentes.

31. Un ejemplo de la actualización contemporánea de la mítica reina a través de un proceso de asimilación visual en RUIZ GARRIDO, B.: "Una nueva Cleopatra. Interrelaciones iconográficas en las imágenes femeninas de seducción del fin de siglo", Actas del XIV CEHA 2002: Correspondencia e integración de las artes, Málaga 2004, 521-43. En este trabajo proponíamos la correspondencia consciente entre una imagen fotográfica de la reina María de Rumanía publicada en 1914 y el perfil histórico y artístico recreado de su legendaria homóloga, como un caso singular de relación entre las artes y de conexiones sutiles y evidentes a un tiempo.

32. Su apasionante vida, la inmortalidad de su recuerdo y la variedad y versatilidad de su figura encuentran su más poético símil en la reina egipcia. ROSE, P.: Jazz Cleopatra. Josephine Baker y su tiempo, Barcelona 1994.

33. La presencia de Cleopatra en Internet resulta abrumadora. Son muy numerosas las páginas monográficas que albergan distinto tipo de información sobre el personaje. Particularmente interesantes son aquellas que alojan galerías de imágenes organizadas cronológicamente como http://www.isidore-of-seville.com/cleopatra/index.html y www.beloit.edu/ classics/ main/courses/history222/julius/cleopatra/ 


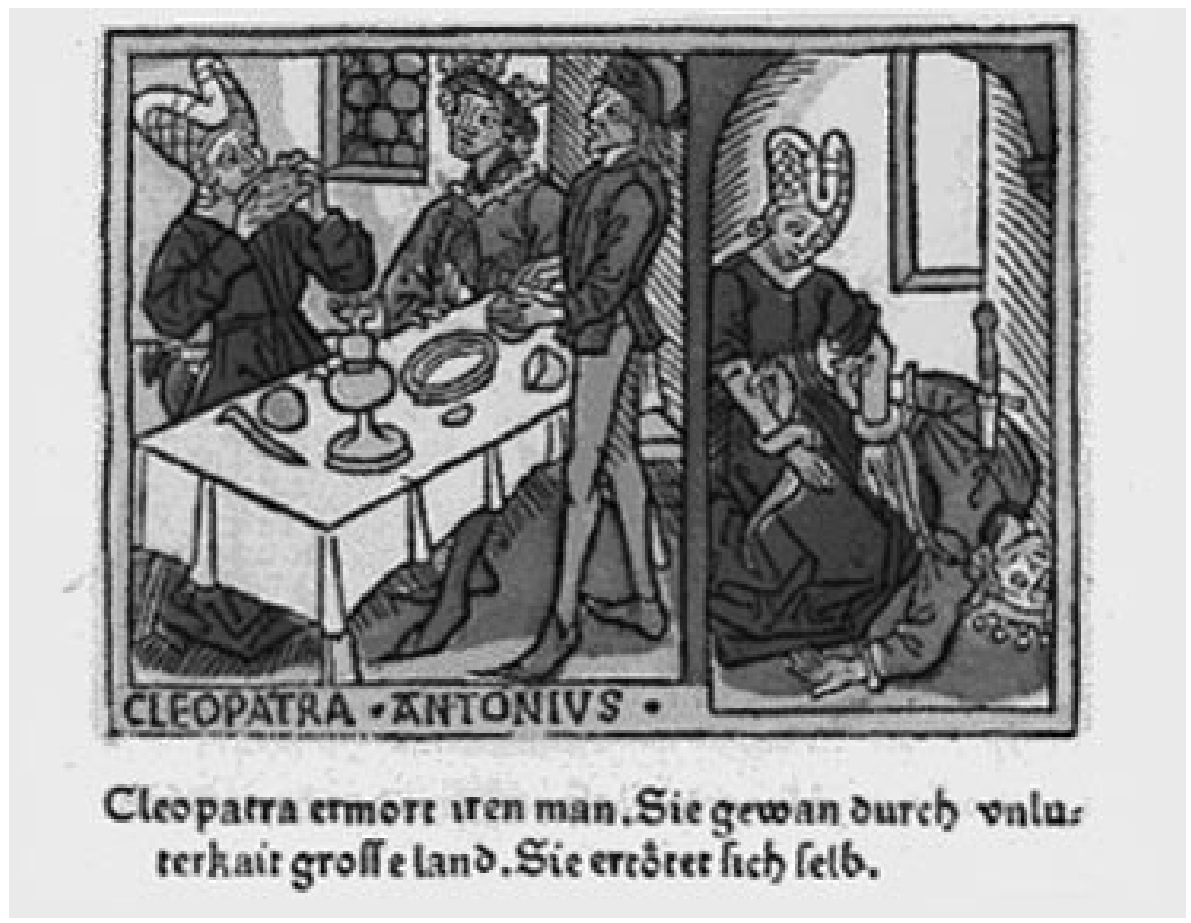

1. Cleopatra. Ilustración de un manuscrito de Bocaccio, 1405.

Tras el vacío iconográfico medieval, serán los cambios ideológicos, filosóficos y estéticos, y el conocimiento de los escritos clásicos, vinculados al humanismo renacentista, los que hagan resurgir el interés por el personaje. La pareja de amantes, Antonio y Cleopatra, co-protagonizan la mayor de las imágenes de la primera mitad del siglo XV. El episodio escogido sienta las bases de lo que será en el futuro el tratamiento prioritario del tema: el suicidio y la muerte, planteado de manera simultánea o, al menos, en la misma escena. Una ilustración para un manuscrito de Bocaccio, fechada hacia 1405, muestra a Cleopatra en el momento previo al fatal desenlace, anunciado por las picaduras de las dos serpientes que se enrollan en los brazos, mientras que Antonio yace muerto a sus pies [fig. 1]. Mucho más impactante resulta la interpretación del mismo asunto en una pintura anónima de 1450 [fig. 2]. Pero las dimensiones trágicas del luctuoso hecho no están planteadas con el mismo nivel de intensidad para los dos personajes, ni se acogen a la misma posición de partida, por lo que los resultados son dispares. La visión que desde la antigüedad adjudica al género femenino una naturaleza instintiva, irracional y peligrosa es la responsable de esta dualidad. Antonio aparece como un 


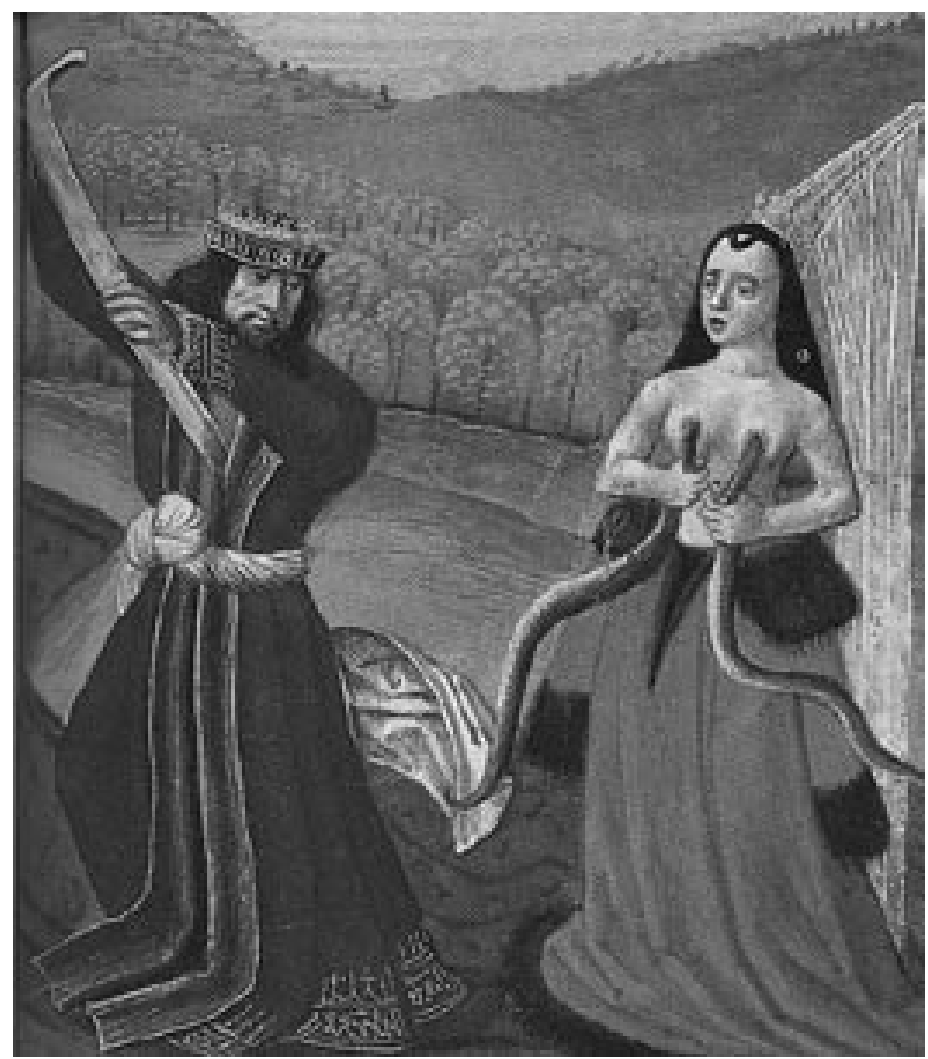

2. Muerte de Cleopatra y Antonio, h. 1450.

rey viril y decidido que apuesta por la muerte como la única salida posible, de ahí su actitud heróica y complaciente. Sin embargo, la soberana, presa de terror, expresa el dolor con el gesto y la pose. De tal calibre es su contingencia humana que el autor crea una simbiosis entre la mujer y los animales que la llevan a la muerte, haciendo que las cabezas de los reptiles, apenas perfiladas, parezcan hundirse en los senos, o salir de ellos.

El carácter narrativo que sustenta estas primeras interpretaciones va cediendo terreno ante propuestas de mayor concisión retórica. La reconsideración de otros aspectos del mito a partir del siglo XVI permite conjugar motivaciones y objetivos heterogéneos en una misma imagen. Cleopatra protagoniza con exclusividad composiciones polisémicas en las que a las condiciones y referencias eruditas se unen cualidades sensoriales que apelan a la exaltación de los sentidos. Es el caso de un interesante grabado de Marcantonio Raimondi (1470-1527) [fig. 3], en el que una Cleopatra descontextualizada de un marco 


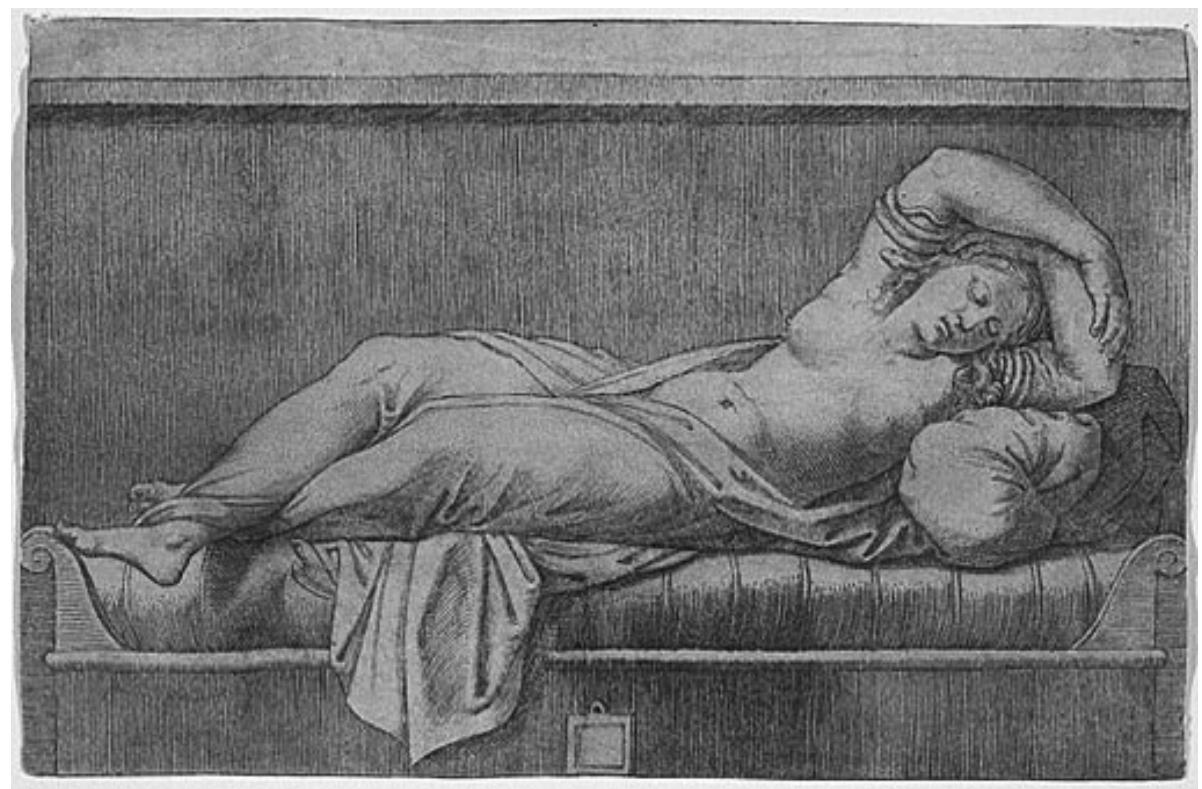

3. Marcantonio Raimondi (1470-1527), Cleopatra.

espacio-temporal preciso yace recostada en un diván en una sugerente actitud conciliadora entre el sueño y el abandono. De esta forma la imagen brindaba la posibilidad de recrearse en la belleza sensual de un cuerpo voluptuoso que se ofrecía sin resistencia a la mirada - y la imaginación - del espectador. Las connotaciones eróticas de la imagen ${ }^{34}$ venían a coincidir con el retrato de la reina trazado por Plutarco en las Vidas, cuyas traducciones proliferarían en estos años finales del siglo XV y principios del XVI. El éxito de este tipo de representaciones quedaría corroborado pocos años después a partir de la adaptación de Tiziano de este perfil iconográfico a su célebre Venus.

Desde los albores del siglo XVI se comprendió que una de las armas más eficaces del personaje era su versatilidad. La asimilación Cleopatra-Venus, presente ya en el texto clásico, es un ejemplo de ello. No sería el único. Un soberbio dibujo de Miguel Ángel (h. 1535) propone la relación entre Cleopatra y la gorgona Medusa a partir de referencias muy sutiles [fig. 4]. La identificación del personaje se consigue con la presencia del áspid mortal rodeando el busto hasta llegar al pecho. Pero el maestro adorna la cabeza con aderezos,

34. A partir de los dibujos de Giulio Romano, Raimondi realizó en 1524 una carpeta de dieciséis grabados eróticos que gozó de gran difusión y fueron objeto de la censura y persecución papal. 


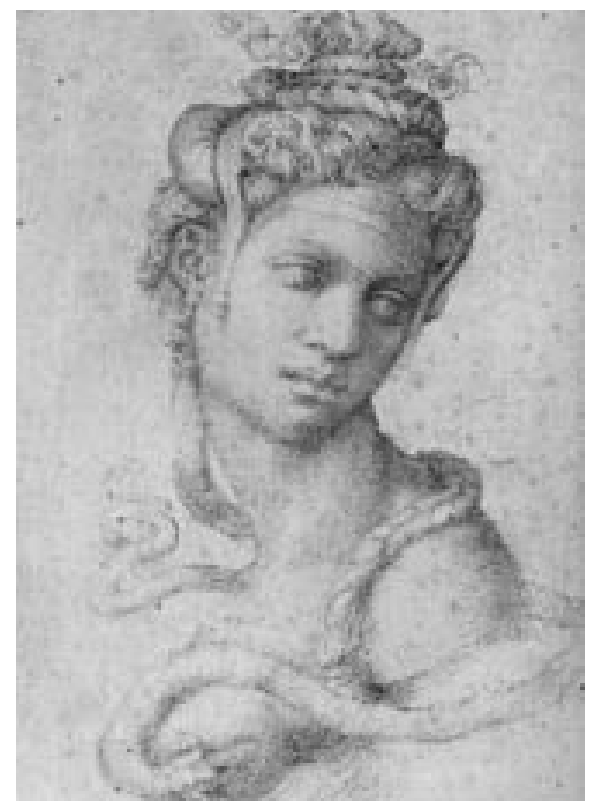

4. Miguel Ángel, Cleopatra, h. 1535.

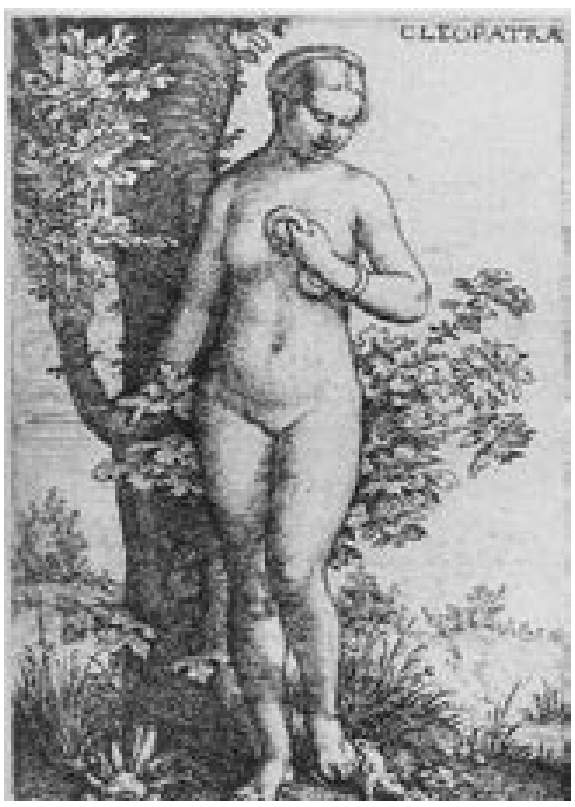

5. Cleopatra. Anonimo flamenco, h. 1550.

mechones y trenzas suspendidas, volátiles, que se entrelazan equívocamente con el cuerpo del reptil. La imponente presencia de la figura y el poder conferido al gesto y a la mirada completan los mecanismos de equivalencia. La simbiosis no pasaría desapercibida posteriormente a Shakespeare. Cleopatra ejerce una atracción medusea, irresistible y aniquiladora, reconocida por el propio Antonio ${ }^{35}$, que ve, además, cómo su identidad masculina se diluye ante la suplantación de roles que personifica Cleopatra. La reflexión sobre este hecho, lugar común en la cultura humanística ${ }^{36}$, está presente también en el dibujo de Miguel Ángel, que traduce su visión en una ambigüedad sexual evidente ${ }^{37}$.

En el proceso de fijación de una imagen recurrente para la representación de Cleopatra surge una nueva analogía. Un grabado flamenco fechado hacia 1550 plantea de forma explícita la vinculación con Eva [fig. 5]. De no ser porque la identidad femenina aparece impresa en la obra, las dudas serían más

35. Op. cit., 77. Véase nota 10.

36. Un análisis de este tema en ibídem, 39 y ss.

37. Sobre la relación entre el dibujo y la naturaleza de su amor por el joven Tomasso Cavalieri véase http://www.casabuonarroti.it/cleo.htm y http://wsu.edu/ dee/REN/MICHEL.HTM 
que razonables. Si bien la serpiente se dirige hacia el seno, la figura muestra su edénico desnudo en un entorno paisajístico absolutamente ajeno al contexto histórico, en clara alusión al paraíso bíblico. El discurso moral implícito hacía a la soberana responsable de la destrucción de un hombre y sus ideales, emulando la perdición que a gran escala había producido su antecesora, y ambas empleando los instrumentos propios de su perniciosa esencia femenina. No obstante, la incertidumbre planteada en el cariz de la leve mueca dibujada en el rostro de esta Cleopatra-Eva, entre la complacencia y el dolor, anunciaba las novedades interpretativas de las representaciones barrocas.

Ningún otro episodio de la apasionante vida de la legendaria reina egipcia sería tan definitorio e impactante como su suicidio. La muerte de Cleopatra copa la producción artística del siglo XVII dedicada a esta temática. La mayor parte de las representaciones escogerá el momento previo al penoso suceso, para mostrar a la soberana consciente de su acto portando entre sus manos el áspid. Es el caso de las obras de Johann Liss (1622-24), Michel Corneille (h. 1650-60), Massimo Stanzione (1630-40), las distintas interpretaciones de Guido Reni (entre 1625 y 1640) y Luca Giordano (h. 1700). Menos numerosas pero sumamente impactantes son aquéllas que presentan a la reina muerta, en soledad o arropada bajo ejemplares composiciones cortesanas, como la de Giovanni Francesco Barbieri Il Guercino (1640-50) y las dos versiones de Guido Cagnacci (1658 y 1660) [fig. 6], o escenas ambiguas en las que Cleopatra parece debatirse entre la vida y la muerte, como la de Pietro Ricci (h. 1700).

De un modo o de otro, las imágenes responden a la "retórica de la sexualidad", un componente esencial en la comprensión del alcance del mito. En este sentido, la aportación de Shakespeare resulta premonitoria: "el discurso de Cleopatra se configura como una retórica de la sexualidad, donde esa economía lingüística contrasta con la potencia de las imágenes uniendo la muerte con el sexo, y concediendo a todo el discurso un peso mitológico que en última instancia sobrepasa la inmediata instancia contextual" 38 .

La sensibilidad barroca resuelve esta vinculación inapelable entre eros y thanatos, proponiendo un juego de dobles lecturas y asociaciones al que el espectador accede activando mecanismos sensoriales. El exaltado dinamismo de las actitudes y los gestos enajenados relacionan el dolor producido por la picadura con el éxtasis sexual, y por extensión, la serpiente mortífera con el elemento fálico. Los recursos empleados para ahondar en la eficacia visual de la imagen son diversos, desde la utilización de la iconografía religiosa de las Dolorosas, como es el caso de Guido Reni [fig. 7], hasta la asimilación con escenas de raptos y violaciones mitológicas, como hace Pietro Ricci.

38. Introducción, op. cit., 60. 


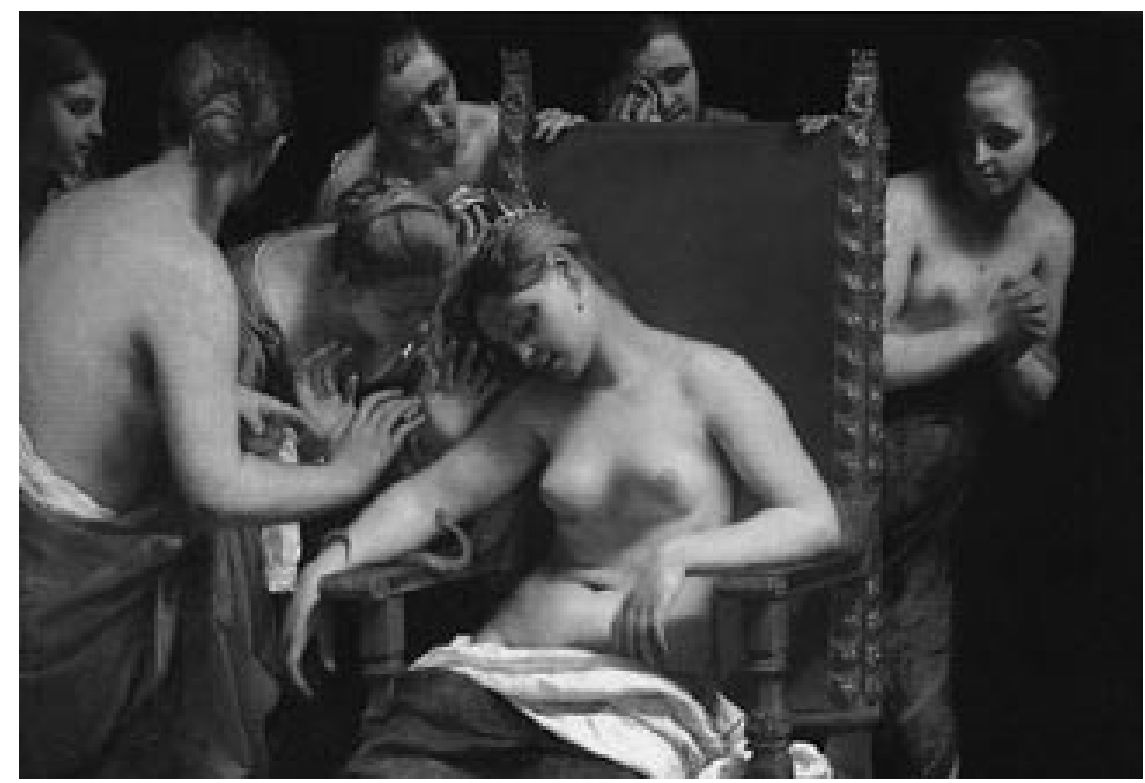

6. Guido Cagnacci, La muerte de Cleopatra, 1658.

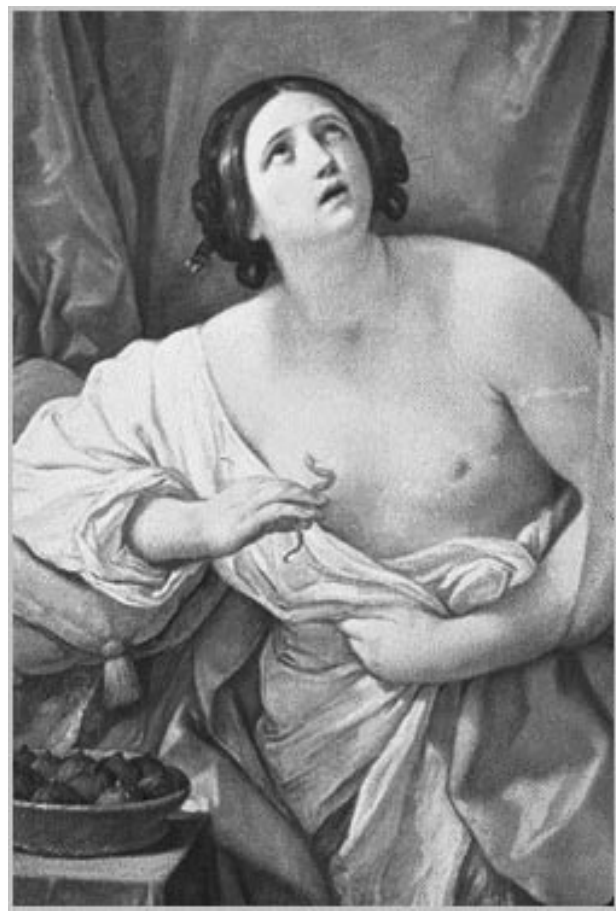

7. Guido Reni, Cleopatra, 1635-40. 
Más excepcionales resultan aún los planteamientos historicistas que recrean algunos episodios ajenos al luctuoso acontecimiento, como El desembarco de Cleopatra en Tarsus (1642-43), de Claude Lorrain o El banquete de Antonio y Cleopatra (1669), del holandés Jan de Bray. Este último será tratado por Tiepolo como una excusa para orquestar una exuberante composición cortesana adaptada a su tiempo, en El banquete de Cleopatra (1743-44), reconvertido bajo un tratamiento más austero en El encuentro de Marco Antonio y Cleopatra (1740-45).

En realidad el siglo XVIII asiste a un decaer general en el tratamiento del tema. Habrá que esperar a las postrimerías de la centuria para que una serie de circunstancias - las expediciones napoleónicas, el conocimiento enciclopedista, los ideales sociales y culturales de la Ilustración - confluyeran en el renacimiento del interés por el mito ${ }^{39}$. Esta perspectiva renovada incidirá también en la visión que se ofrece de la muerte de la reina. Jean-Baptiste Regnault, en una obra fechada hacia 1790, presenta a una Cleopatra actualizada, posando en el momento previo al suicidio [fig. 8]. Desde los presupuestos ilustrados, resueltos bajo la estética neoclásica con exactitud técnica, pulcritud en el dibujo y colorido brillante, el óbito se afronta con dignidad heróica, a la manera de los grandes personajes de la historia. Sin embargo, el artista no puede sustraerse a la carga erótica del asunto y hace que su Cleopatra ofrezca el pecho no sólo a la picadura mortal de la serpiente que acecha impaciente entre sus manos, sino a la mirada de un espectador subyugado ante la sugerente y prometedora sonrisa.

Será la sensibilidad romántica, y su renovación finisecular, la más implicada en su representación y popularidad. El episodio preferente insiste en el dramático suicidio de la reina. Chasseriau (1845), Thomas Ridgeway Gould (1873), Thomas Frances Dicksee (1876), Edmonia Lewis (h. 1876), Juan Luna (1880), Arthur Reginald (1892) o Valentine Cameron Prinsep, trataron el tema, tanto desde posiciones ortodoxas y académicas como desde apuestas arriesgadas. Uno de los trabajos más impactantes es el realizado por Jean-Andre Rixens en 1874 [fig. 9]. Al interés arqueológico por hacer creíble la escena, repleta de todos los elementos de atrezzo necesarios para contextualizar, se une una retórica que apela directamente a la emotividad del espectador. El sensual cuerpo de Cleopatra yace sin vida mostrando una blancura marmórea potenciada por el foco de luz teatral. El disfraz histórico brinda la oportunidad de hacer permisibles a la mirada imágenes que de otro modo resultarían escandalosas. Un público acostumbrado a los códigos de la ambigüedad saciaba

39. QUESADA MONGE, R.: "Mujeres eternas. Enheduanna-Hasehpsut-Nefertiti-Cleopatra", Escáner Cultural 23, 2000. Revista virtual alojada en la página: http://www.escaner.cl/ escaner23/perfiles.htm. Véase también CLAYTON, P.: Op. cit. 


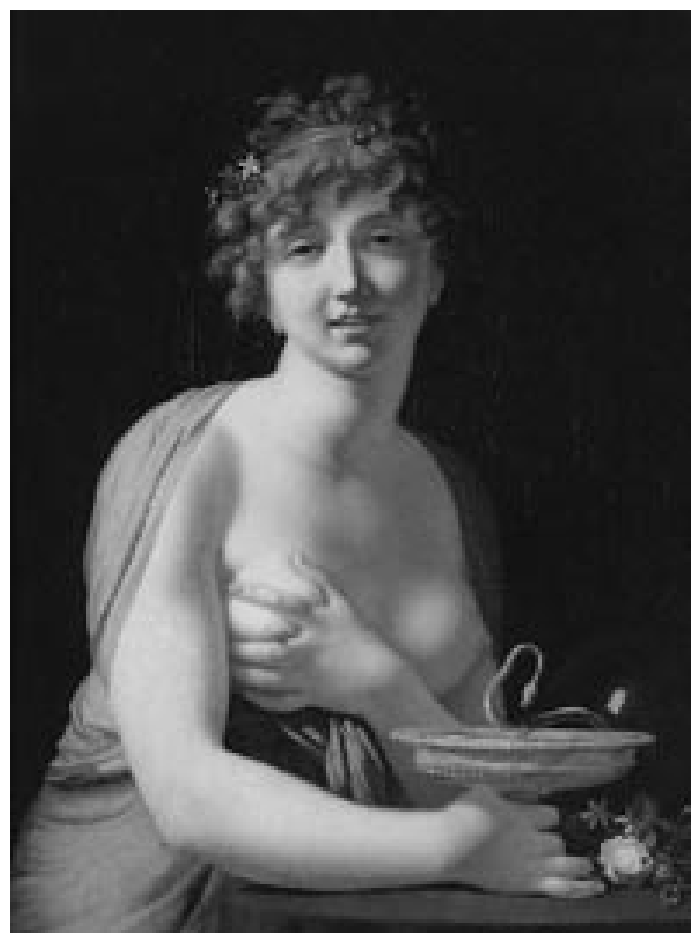

8. Jean-Baptiste Regnault, Cleopatra, h. 1790 .

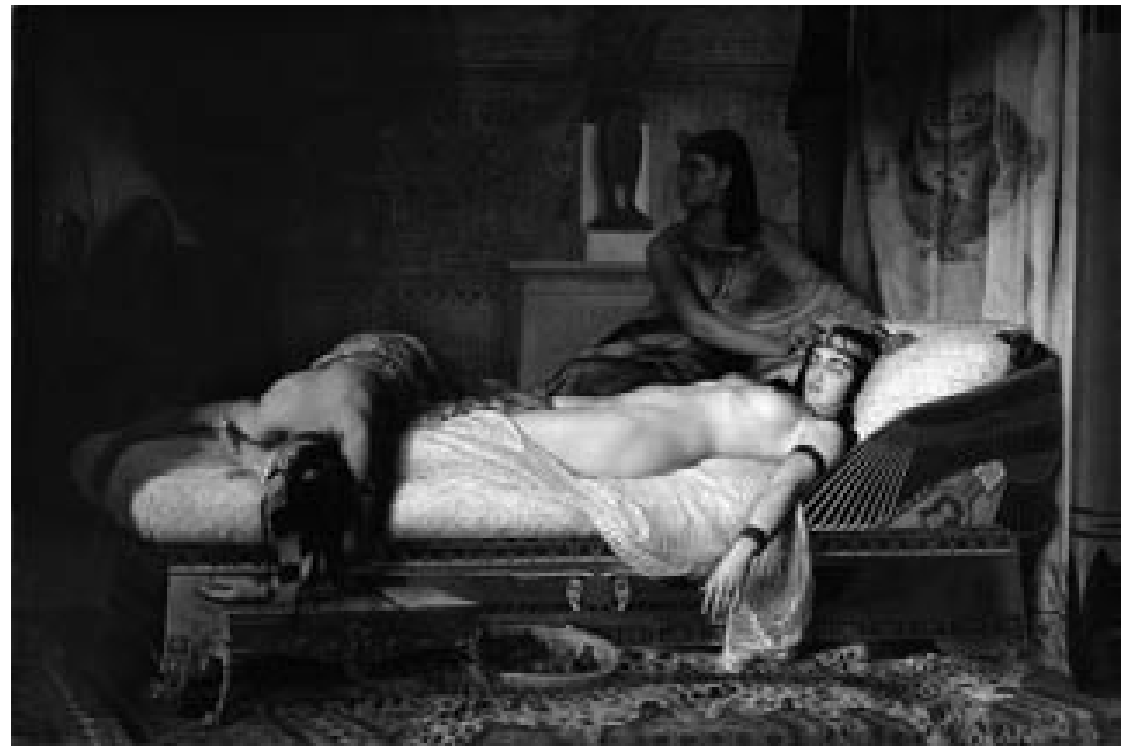

9. Jean-Andre Rixens, La muerte de Cleopatra, 1874. 


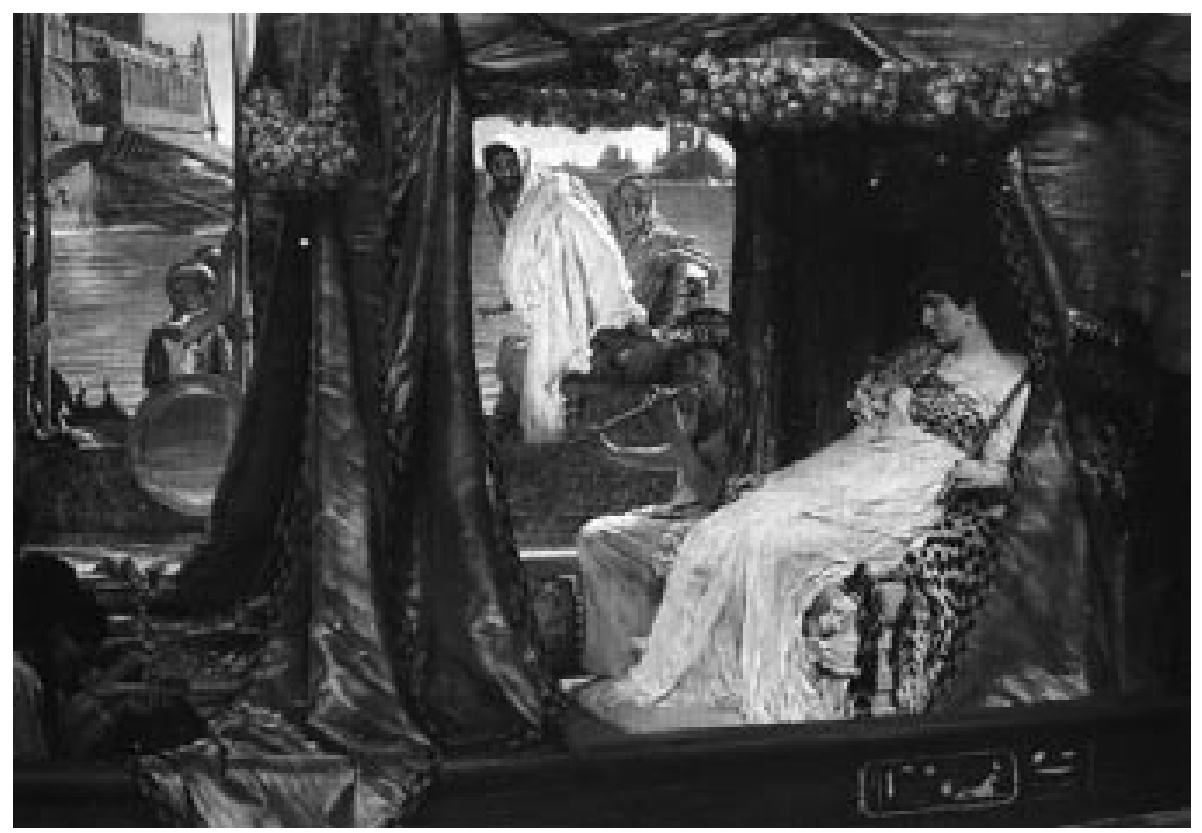

10. L. Alma-Tadema, El encuentro entre Antonio y Cleopatra, 1883.

sus deseos morbosos al poder contemplar un cuerpo femenino desnudo que se ofrecía sin resistencia.

Esta obra ponía en evidencia una de las obsesiones románticas más explotadas tanto desde la plástica como desde la literatura, y llevada a sus últimas consecuencias por las opciones finiseculares decadentes: el "eros negro" 40 , en referencia a la comunión entre voluptuosidad, deseo y muerte o dolor en el más amplio de sus espectros.

A pesar de su recurrencia, el suicidio no será el único asunto que interese a los artistas decimonónicos. El peso del género histórico, unido al éxito, ya comentado, del exotismo orientalista, propiciaría una ampliación de la temática egipcia relacionada con la vida de la legendaria reina. No obstante, estos dos principios rectores ofrecían la posibilidad de tratar episodios variados en respuesta a objetivos e intereses igualmente dispares. El texto de Shakespeare sirve de referencia a Gerome para trabajar un evento anecdótico en Cleopatra

40. Un estudio en profundidad de este tema en la literatura y el arte en PRAZ, M.: La carne, la muerte y el diablo en la literatura romántica, Caracas 1969; LITVAK, L.: Erotismo fin de siglo, Barcelona 1979, 83-156; AA. VV.: Amor y muerte en el Romanticismo, cat. exp., Madrid/Barcelona 2001. 
sorprende a Julio Cesar (1866). La ocurrente aparición de la soberana ante el romano envuelta en una alfombra se convierte en un interesante material cinematográfico. Todas las versiones lo aprovecharían para presentar, de forma original y sorprendente, a sus actrices protagonistas. L. Alma-Tadema escoge el primer encuentro entre los amantes en una escena más prometedora que explícita para dejar que la imaginación complete el resto. En realidad El encuentro entre Antonio y Cleopatra (1883) [fig. 10] es una excusa tanto para demostrar sus habilidades técnicas como para proponer la posibilidad de adentrarse en el hedonismo de la cultura oriental, al mostrar a la reina en un primer plano en una actitud relajada, rodeada de todos los elementos propios de una vida placentera. En esta misma línea, aunque sin el apoyo del relato, se sitúa Cleopatra en las terrazas de Filé de Frederick Arthur Bridgman (1896); la recreación de un asunto intrascendente redunda en los efectos sensoriales tratados con cierto gusto esteticista. Otro de los ingredientes de la retórica orientalista ponía el acento en los aspectos más perniciosos del mito. En Cleopatra ensayando el veneno con sus amantes (1887), Alexandre Cabanel apela al discurso de la fatalidad en un montaje cargado de elementos contextualizadores con los que arropar la presentación de la reina como una mujer despiadada y cruel que asiste altiva, arrogante e impasible al truculento experimento [fig. 11].

El siglo XIX trajo además una nueva visión plástica del mito. La comprensión de la fuerza visual de la soberana propiciará el tratamiento de su figura en la plenitud de su poder, sin necesidad de aditamentos escenográficos,

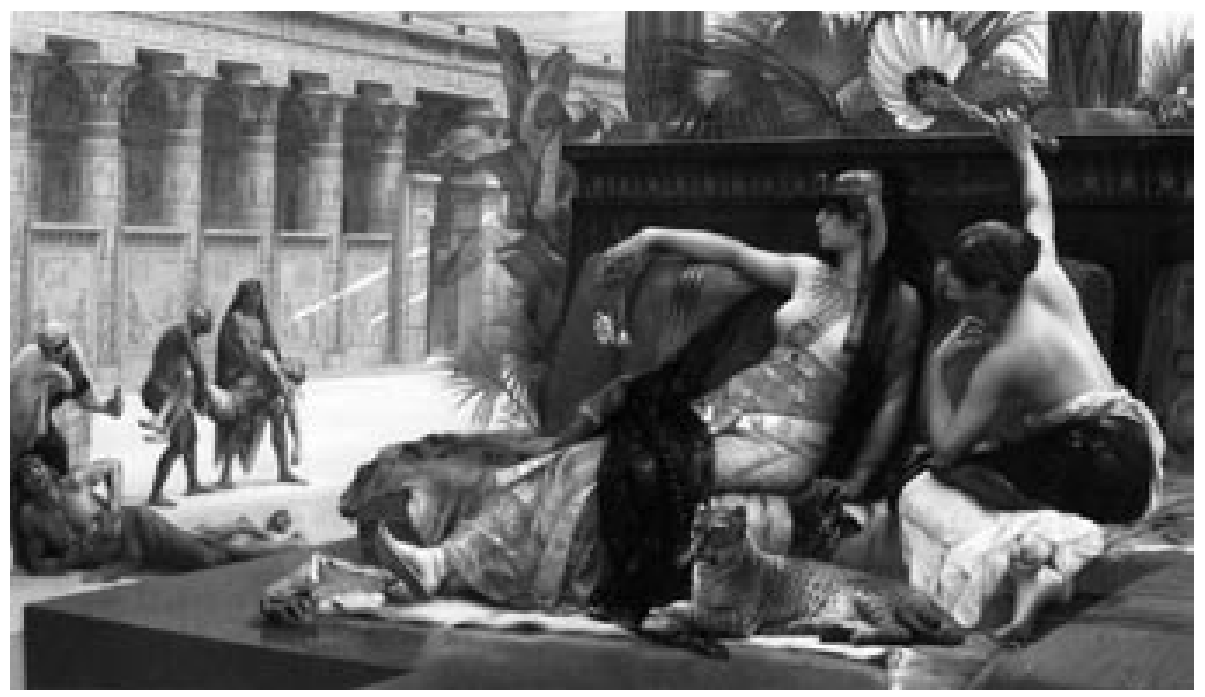

11. Alexandre Cabanel, Cleopatra ensayando el veneno con sus amantes, 1887. 


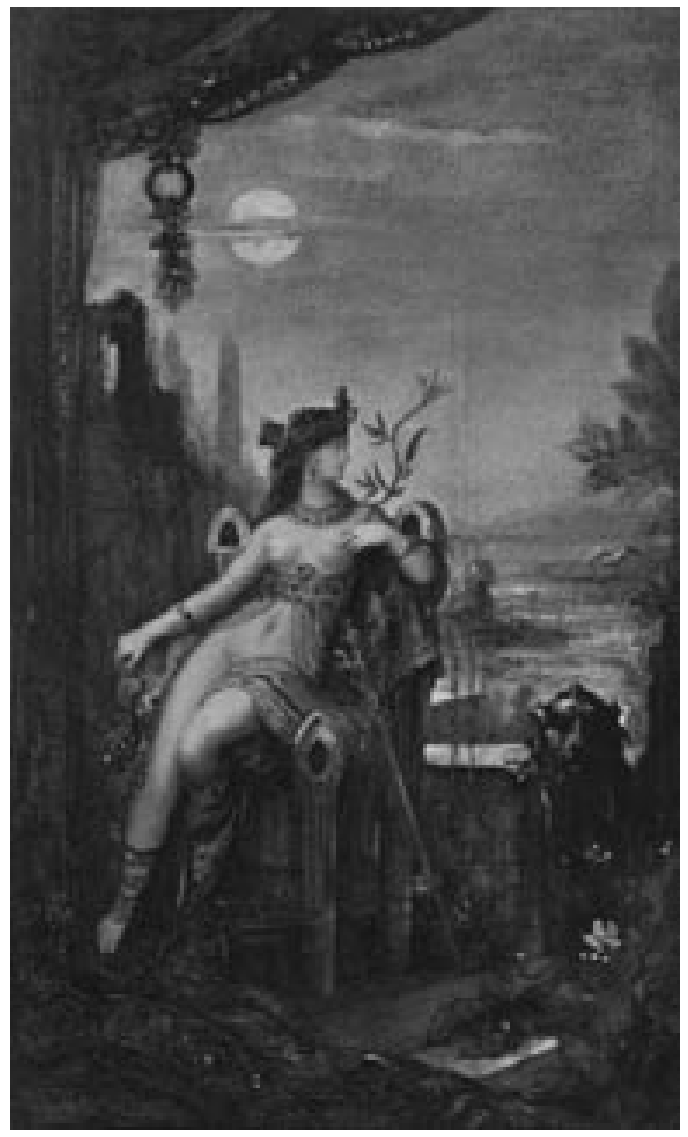

12. Gustave Moreau, Cleopatra, 1887.

referentes episódicos o composiciones grandilocuentes. Delacroix ya había estimado este componente en su Cleopatra y el campesino (1838) al mostrar a la reina ajena a la presencia masculina, ensimismada en sus pensamientos, abrumada por el peso del destino sin perder la dignidad. Una Cleopatra igualmente reflexiva aparece en la escultura de William Wetmore Story (1858). Sugerente, exultante y consciente de su atractivo la recrea Mosè Bianchi en Cleopatra reina de Egipto (h. 1864-65). Dominante, aunque rodeada de cierto aire malsano, lo hará John William Waterhouse en 1888. Afrontando la preparación de la muerte como sólo lo haría una diosa se presenta de la mano de William Henry Margetson. Acorde con las descripciones literarias, las representaciones de este tipo permitían ahondar en las cualidades más insondables del mito. La Cleopatra de Gustave Moreau (1887) concentra lo inescrutable de su condición en una rutilante composición preciosista de recargada atmósfera, más sugerente que expresa, como su propia esencia se perfila [fig. 12]. No en balde Moreau será el maestro finisecular clave en la recreación del eterno femenino.

En el extremo del decadentismo esteticista, la Fantasía Egipcia de Charles Allen Winter (1898) proponía, en clave alegórica, un ejercicio de estímulos sensoriales e imaginativos, traspasando la contingencia histórica y el relato.

El siglo XX en absoluto ha sido ajeno al tratamiento plástico del personaje. Nos interesa particularmente la apropiación que han realizado las artes relacionadas con la cultura de masas. La moda, la decoración, la publicidad, la ilustración gráfica, el cómic, entre otros, han contribuido a la reactualización, popularización y banalización de un mito que continúa subyugando. 


\section{UNA REINA DE PELÍCULA. CLEOPATRA COMO PERSONAJE CINEMATOGRÁFICO}

El interés de las artes plásticas por el personaje fue compartido por el cine desde sus comienzos, como corrobora el corto del pionero George Méliès fechado en 1899. A partir de esta precoz experiencia, de tan sólo cinco minutos, los títulos recorren todo el siglo XX con apuestas adecuadas a los gustos de cada momento y resultados varios ${ }^{41}$. Entre las películas dedicadas a la reina de Egipto destacamos cuatro cintas consideradas prototipos de otros tantos periodos y registros de la historia del séptimo arte. La Cleopatra por excelencia del cine mudo no podía ser otra que Theda Bara, quien actuara a las órdenes de J. Gordon Edwards en 1917. El espectacular éxito de la cinta llegó a relegar y hacer olvidar el largometraje que en 1912 protagonizara y produjera Helen Gardner, una de las primeras "vamps" del cine mudo, con el título original de Helen Gardner in Cleopatra ${ }^{42}$. Años después, la censura impuesta por el tristemente famoso Código Hays provocaría la destrucción de todas las copias de la Cleopatra de Gordon Edwards, calificada de obscena. Algunos trozos conservados en museos y las fotografías nos permiten intuir la espectacularidad y elaboración de los escenarios y del vestuario lucido por la actriz. El hecho de que no figure en los títulos de crédito ningún responsable de vestuario, ha llevado a pensar a algunos historiadores que fue la propia Theda Bara la encargada de los diseños, aunque esta idea, bastante improbable, únicamente contribuye a aumentar la leyenda forjada a su alrededor ${ }^{43}$. Lo cierto es que todos los elementos artísticos giran entorno al objetivo de ensalzar la figura de la protagonista, aunque para ello hubiera que sacrificar la rigurosidad histórica. Gasas, perlas y bordados colocados estratégicamente para velar la desnudez, se combinaban con abalorios y motivos de inspiración egipcia, como tocados con forma de pirámides y serpientes enroscadas para dar forma a los corpiños ${ }^{44}$; el imprescindible maquillaje

41. Entre las páginas con información cinematográfica dedicadas a Cleopatra destacamos: http:// uk.imdb.com/M/title-substring?title=cleopatra (Internet Movie Database, la mayor base de datos de películas en Internet) y http://www.wepwawet.nl/films/default.htm (incluye una relación de películas desde 1899 a 2007, con una sucinta ficha técnica y comentarios).

42. ESPAÑA, R. de: El Peplum. La Antigüedad en el cine, Barcelona 1998, 241-2.

43. Uno de los elementos del vestuario que más llamó la atención, un sujetador-corpiño realizado con cintas de metal enroscadas en forma de serpiente, había sido lucido por la escritora y actriz Sidonie Gabrielle Colette en las representaciones de la pantomima Rêve d'Égypte, entre 1907 y 1912. Véase la fotografía y la información sobre la obra en LOTTMAN, H.: Colette. Una vida, Barcelona 2006, 94-6.

44. Para una mayor profundización en el vestuario de las Cleopatras seleccionadas véase CLAUDON, C. D.: "The Cleopatra Costume on Stage and in Film", artículo alojado en la página web http://www.davidclaudon.com/Cleo/Cleopatra1.html 


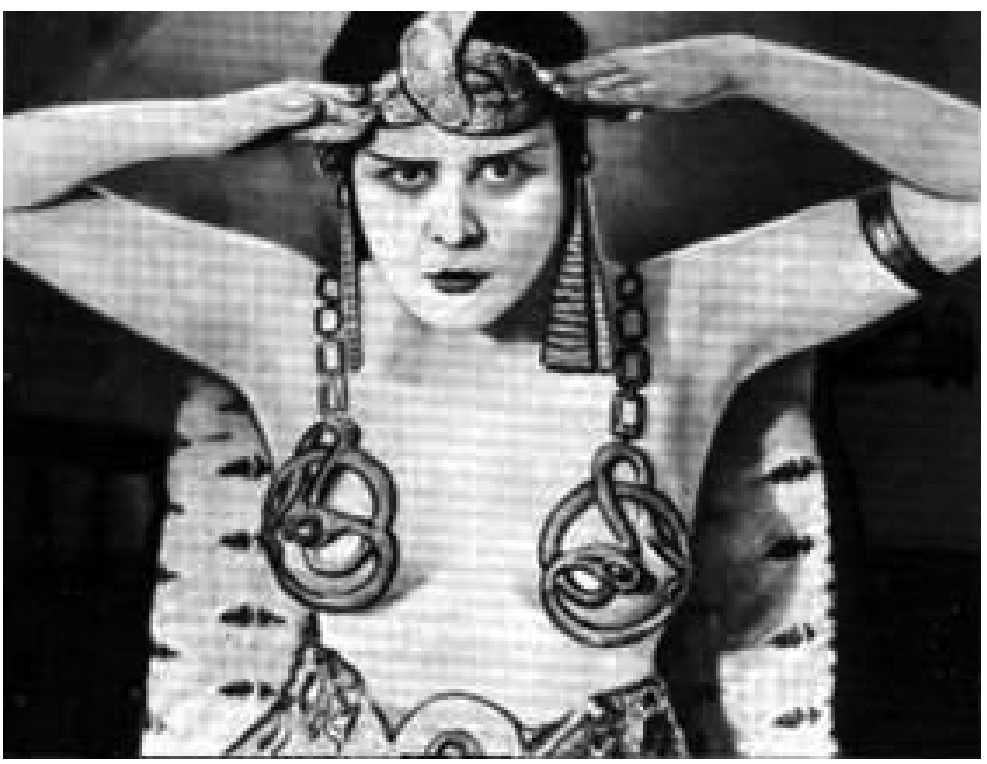

13. Theda Bara en Cleopatra, 1917.

marcado de los ojos, para redundar en los oscuros misterios del personaje, completa el efecto. El resultado es una Cleopatra suntuosa, seductora y enigmática, la encarnación perfecta de la fatalidad femenina [fig. 13].

En 1934 Cecil B. de Mille se hace cargo de una nueva versión, para la que se contó con una de las grandes estrellas de los años 30 y 40: Claudette Colbert. El director fue consciente de la necesidad de actualizar el drama épico, incidiendo en la modernización de la imagen y en la claridad de la carga erótica, recursos empleados para lograr la identificación y el enganche del público. La fórmula pasaba por convertir a la mítica reina en una mujer actual que respondiera a los cánones estéticos de ese tiempo. La moda imponía un estilismo que combinara glamour, elegancia y la dosis exacta de picardía. En esos años hacía furor la flapper, la chica de formas estilizadas, no demasiado exuberantes, andróginas, tanto en el comportamiento activo y resuelto como en el look, algo volátiles y deseosas de vivir intensamente. Sólo quedaba convertir a esa joven en una reina, pero una reina chic. La caracterización de la actriz responde a este objetivo. Claudette Colbert lució pelucas de corte recto y cabello negro muy liso y brillante, atrevidos vestidos de lamé y espectaculares complementos y tocados con motivos egipcios para enmarcar un rostro blanquísimo de labios rojos intensos [fig. 14]. 


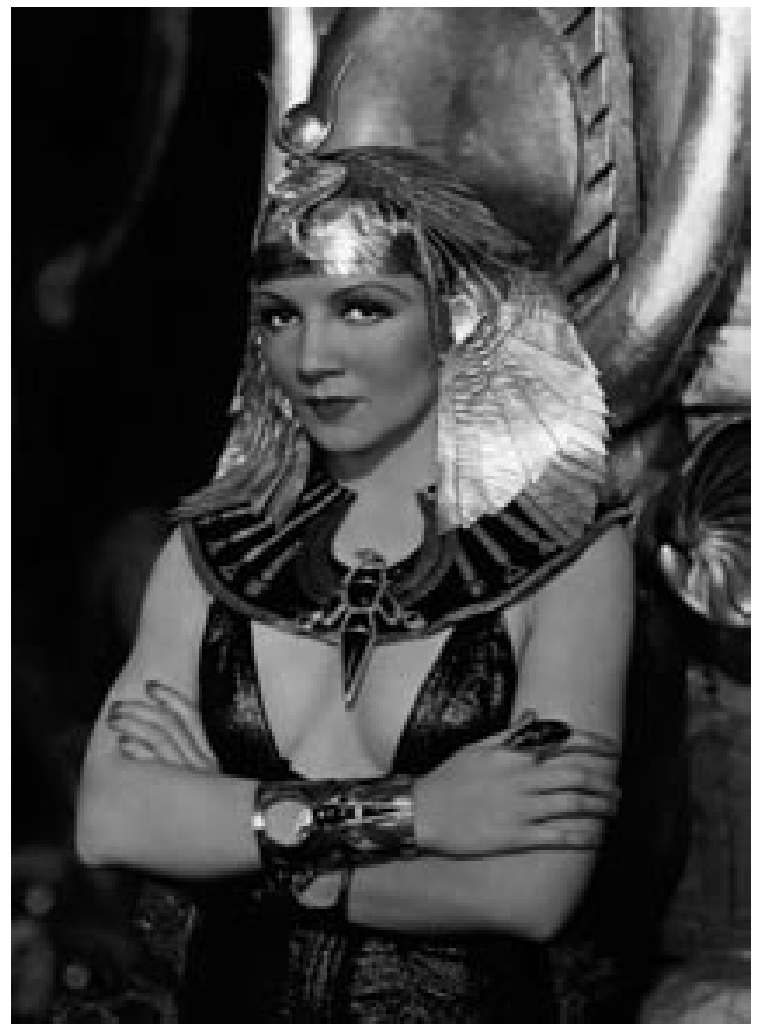

14. Claudette Colbert en Cleopatra, 1934.

Igualmente la puesta en escena ${ }^{45}$, apoyada en una ambientación y mobiliario Art Déco, se pone al servicio de la consecución sensual. Un derroche de escenas eróticas, en las que los movimientos estaban coreografiados hasta el detalle ${ }^{46}$, y una corte de burbujeantes flappers, ayudan a crear la atmósfera buscada. Algunos de los elementos de atrezo hacen referencia explícita a este carácter. Es el caso del lecho en el que la reina recibe a Julio César, adornado con dos leonas aladas y dos largos tallos de loto cerrado de clara asimilación fálica. En este sentido, en una de las escenas de mayor contenido erótico, se recurre a la desacralización y perversión de un perfil iconográfico utilizado por el decadentismo finisecular: la pesca de unas pícaras y divertidas jóvenes convertidas en algas marinas, o la recreación de un espectáculo circense donde unos sensuales leopardos hembra son amaestrados por aguerridos domadores a golpe de látigo para saltar por aros ardientes. Para compensar, y como concesión a una particular pugna entre el refinamiento y la vulgaridad, otros recursos eróticos resultan más sutiles. $\mathrm{Al}$ encuentro privado entre Cleopatra y César asiste una paloma. La reina va a proponer al romano un acuerdo para compartir el poder a través de un matrimonio de conveniencia, y que mejor señal de su buena voluntad que portar

45. Cecil B. DeMille era un maestro en sacar el máximo partido de las piezas de decorado modestas e incluso reutilizadas, como las empleadas en Cleopatra. ESPAÑA, R. de: $O p$. cit., 244.

46. De España compara la coreografía montada por Cleopatra para seducir a Marco Antonio con las Ziegfeld Follies, espectáculos musicales y de variedades montados en Broadway entre 1907 y 1931. Ibídem, 243-4. 
el ave de Afrodita, regalo habitual entre los amantes y presagio favorable de paz y armonía. La reina del gineceo, joven juguetona y mujer de inteligencia y astucia singulares, debía emplear todas las armas a su alcance para conseguir sus deseos.

La interpretación de la actriz hacía de su personaje una mujer de coraje, decidida, entregada plena y activamente al amor, aunque sin perder su seguridad en sí misma y su dominio de la situación, tal y como se esperaba de las mujeres emancipadas a las que prestaba un modelo de comportamiento.

Mucho más rico en matices es el perfil que se ofrece de la reina de Egipto en César y Cleopatra, adaptación cinematográfica, rodada a las órdenes de Gabriel Pascal en 1945, de la obra teatral de George Bernard Shaw, quien trabajó asimismo en el guión. Vivien Leigh da vida a una menuda y nada exuberante Cleopatra, educada para ser reina por César (Claude Rains) que actúa como pigmalión. El físico de la actriz y sus soberbias dotes interpretativas resultan claves en la caracterización del personaje creado por Shaw, preocupado por mostrar los diversos componentes del estereotipo femenino encarnado por la soberana egipcia [fig. 15]. La esencia dual se pone de manifiesto en la transformación física y moral que sufre la protagonista. Esta Cleopatra-Lolita, una inocente niña juguetona, caprichosa y malcriada, "divina criatura" "niña

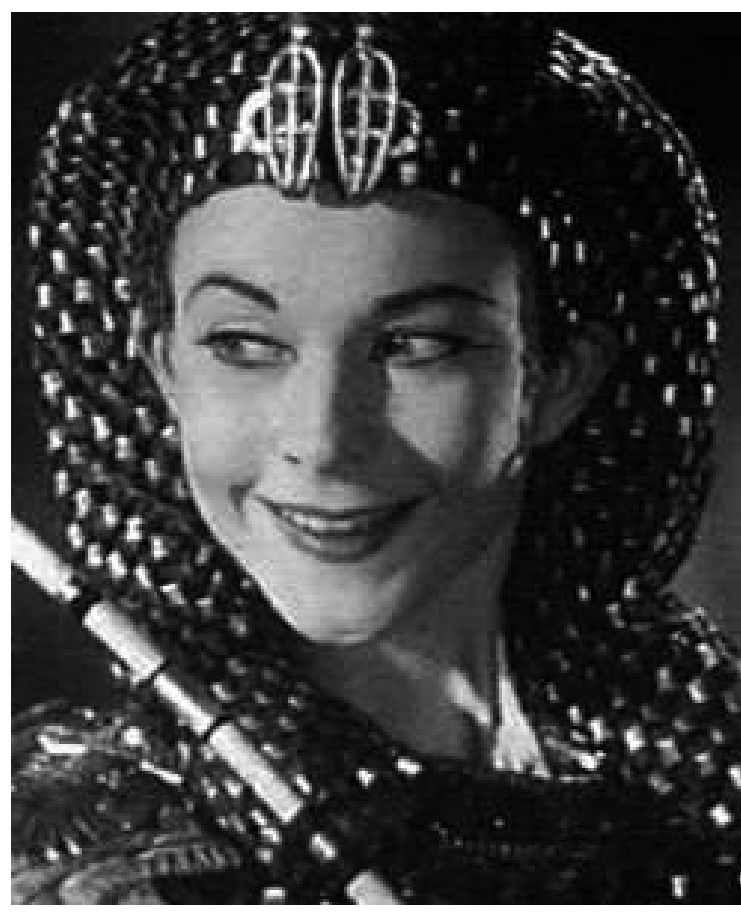

15. Vivien Leigh en César y Cleopatra, 1945. loca", "gatita" y "palomita", como la llama César, coqueta, atraída por los jóvenes de brazos potentes, se va convirtiendo en una mujer-reina cruel, dotada para el engaño, peligrosa y voluble en sus cambios de humor. Su ambición queda clara desde el principio cuando le confiesa a su "profesor" el carácter de su aprecio: "te amo por haberme hecho reina". Los cambios de vestuario coinciden con los de talante: desde una sencilla túnica para el primer encuentro con el romano a los pies de la esfinge, hasta la sofisticación de los trajes y accesorios lucidos 


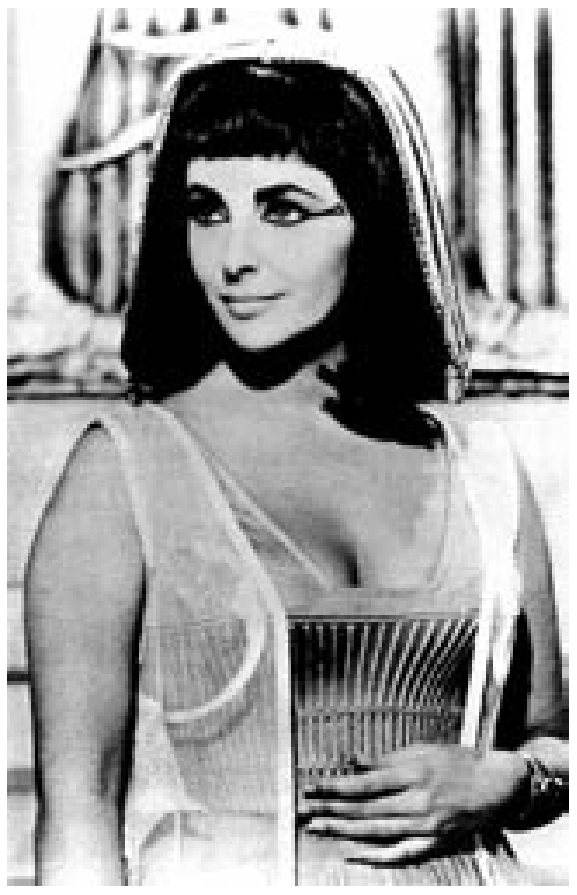

16. Liz Taylor en Cleopatra, 1963.

en las sucesivas escenas, en las que gana en sensualidad para atraer a César o actuar como soberana hablando de asuntos de gobierno o recibiendo audiencias. Todos advierten la metamorfosis: "eres lo que los romanos llaman una mujer moderna", elocuente opinión que, dado el tono general del texto, bien podía responder a la mordaz sátira de las condiciones asociadas a la modernidad femenina.

Sin embargo, la fama de Cleopatra en el cine la debemos a la versión realizada en 1963 por Joseph L. Mankiewicz, interpretada por Elisabeth Taylor y Richard Burton en los papeles principales. Todo en esta cinta respondió a lo que se esperaba de una superproducción de Hollywood ${ }^{47}$. El rodaje se convirtió en sí mismo en un guión cinematográfico, a juzgar por los seis años empleados, los cambios de localizaciones y estudios, unos costes desmesurados y el romance vivido por la pareja protagonista, entre otros motivos. La película se puede considerar un derroche en todos los sentidos: de belleza y exuberancia, de vestuario - la estrella lució unos cuarenta vestidos -, de espectacularidad de los decorados, de tiempo y de dinero. No obstante, Cleopatra ya nunca podría despojarse de la impactante fisonomía prestada por una de las mujeres más bellas de su tiempo. En nuestro recuerdo la reina egipcia tiene el rostro y el cuerpo de Liz Taylor. A la creación de esta imagen contribuyó la caracterización física y el rol desempeñado por el personaje, encarnación perfecta de la característica unión de pasión y política [fig. 16]. Aunque se consiguiera de manera desigual, hubo un interés por alcanzar la exactitud histórica, sobre todo en los accesorios. De ahí que, a pesar de que el vestuario estuviera al servicio del realce de los encantos físicos de la actriz, los accesorios - el báculo, el flagelo, el ureo, las coronas - y los peinados, respondieran a referencias egipcias expresas, como la establecida con el célebre busto de Nefertiti del Museo Egipcio de Berlín. 


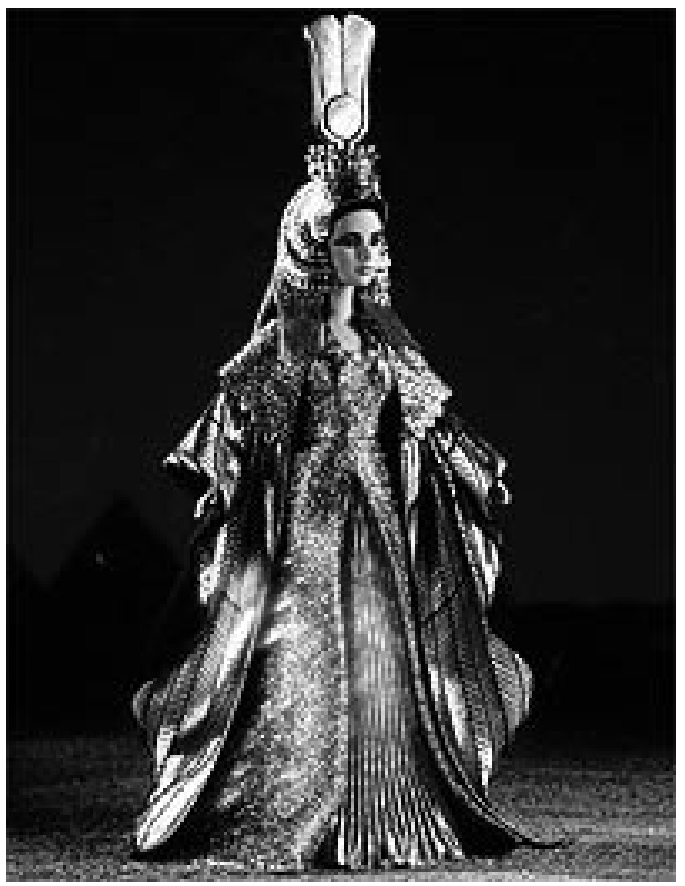

17. Barbie Liz Taylor como Cleopatra (Serie Leyendas de Hollywood), 1963.

Coincidiendo con el estreno de la película de Mankiewicz, salió al mercado una muñeca Barbie de Liz Taylor en el papel de la reina egipcia [fig. 17]. También Claudette Colbert fue inmortalizada en una muñeca que recordaba su legendaria actuación. Era una forma de ganar para la causa a un público aprendiz de femme fatale. Cleopatra se reinventa tras sus múltiples rostros, pero la esencia del perfil que nos ha cautivado desde siglos sigue siendo el mismo. 